\title{
Development of collaboration in sustainable agribusiness cluster
}

\author{
Tomy Perdana ${ }^{1}$, Mahra Arari H., ${ }^{1}$ Fernianda Rahayu H. ${ }^{2}$, Tetep Ginanjar $^{2}$, Ajeng Sesy N.P. ${ }^{2}$ \\ ${ }^{1}$ Department Agro Socio-Economic, Faculty of Agriculture, Universitas Padjadjaran, Sumedang, \\ Indonesia \\ 2. Agricultural Logistics and Supply Chain System (AGRILOGICS) Research Group, Faculty of \\ Agriculture, Universitas Padjadjaran, Sumedang, Indonesia.
}

\begin{abstract}
There is tendency towards sustainable agricultural production to fulfill food security. It ensures that agricultural production is carried out in a sustainable way. Indonesia as developing country has rapid growing population. It will impact to the food security and food demand. That condition is challenging to develop sustainable agricultural production. Meanwhile, the sustainable agricultural production needs interaction and collaboration throughout the agricultural supply chain that involve multistakeholders. This study was conducted in Gemah Ripah 2 farmer group in Kuningan District which has collaboration activities with multistakeholders (i.e. Universitas Padjadjaran, Bank Indonesia region Cirebon, local government in Kuningan District, and Universitas Kuningan) in the development of sustainable agribusiness cluster. The sustainable agribusiness is a combination between animals (cattle, sheep, and fish), and plants (rice, shallot, chili, and secondary plants). Each subject on sustainable agribusiness (livestock and plants) is linkage and complement for each other. This study was aimed to analyze the potential of collaboration process in sustainable agribusiness cluster. Drama theory approach can illustrate the episodes that showed the dilemmas in the collaboration of sustainable agribusiness cluster, whereas a collaboration framework is used to initiatives for resolving dilemmas.
\end{abstract}

\section{INTRODUCTION}

Agricultural is critical for both economic growth and poverty alleviation and dominated by smallholders. Commonly, smallholders are often faced with several hamper, i.e., lack of basic information, inadequate market information, high operating cost, lack of business unit, limited value added to farm production in the rural areas, etc. Development sustainable in agribusiness is about a balancing farming system, social and environment issues, and financing access. Sustainable agribusiness is one of the developing techniques that is utilization of natural resources in agricultural system to fullfill people needs and also to maintain quality of ecological environment as well as it needs integration between livestock and agricultural that has linkage with all stakeholders. The relationship between stakeholders are pull factor in the agricultural and sustainable economic growth on rural areas (Pasandaran et al., 2006). In addition, Sustainable agribusiness is a phenomenon in developing agricultural supply chain, regard with it, the development of sustainable agribusiness in developing countries is exacerbated by poverty, leading to tremendous problems of employment, infrastructures and transportation, food supply chain, and environment protection (De Bon, et al., 2010).

\footnotetext{
${ }^{1}$ Corresponding author: tomy.perdana@unpad.ac.id/ mahra.arari@gmail.com

2 tetepginanjar@gmail.com/ferniandarahayu@gmail.com/ ajengsesynurpratiwi@gmail.com
} 
The application of sustainable agribusiness can be done by developing agribusiness cluster. Business clusters are complex and informally integrated systems of entrepreneurship, business skills, knowledge, research and development, innovation, technology, commercialization, production, quality management, marketing, international trade, productivity, investment, convergence, competitiveness, profitability, and growth. The sustainable agribusiness cluster is the integration between ecological agricultural and sustainable competitive advantage, emphasize the aspects of geographical and networks of stakeholders in agribusiness supply chain (Porter, 2000; Toma, 2009; Geldes et al., 2015) and deemed able to overcome the weakness of the smallholders in rural areas to respond the competition and globalization (Matopoulos et al., 2005). Meanwhile, the ecological agribusiness emphasis on the sustainable use of inters resources (e.g. ecological, economics, and social) rather than the use of external resources (Van't Hooft, 2013).

The agribusiness cluster is connecting farmers, local entrepreneurs (involved in supplier and channel value chains), financial services and business development services in the target region (Toma, 2009). In Addition, agricultural supply chain in developing countries are commonly involve multi-stakeholders i.e., farmers, supplier or trader, market, and other stakeholders (government, university, etc.). The collaboration is one of the social interaction that has several activities to achieve a goal with understanding and responsiblity of each part. Collaboration of sustainable agribusiness cluster development needs synergy, integrity, empathy, and enthusiasm from all stakeholders to gain a better idea in services innovation, collaboration action, and product image in consumers as well as each party having the same position.

Development collaboration in sustainable agribusiness cluster has several dilemmas that hamper their collaboration and should be eliminated the collaboration goals. To reduce the dilemmas, each party cannot depend only on rationality but also have to consider the influence of emotions, hidden agenda, and irrationality (Howard, 1999). Collaboration for agribusiness actors have two emotion sides, there are; positive emotion (empathy, integrity, enthusiasm, and synergy) and negative emotion (blaming, regret, anger, un-desire, and hostility) and those are strategies to know further and influence the preference from other supply chain actors. In regard to development of the understanding about emotions, in agribusiness collaboration needs to develop efforts to support the succession of the collaboration. According to O'malley (1998), sustainable value cannot be creating when each actor tries to achieve their own profit.

Based on that statement, Gemah Ripah 2 farmer group has already developed collaboration with Universitas Padjadjaran and other stakeholders. This study was aimed to analyze the potential of collaboration process in sustainable agribusiness cluster development between the main stakeholders. This study contribute to the current knowledge of sustainable agribusiness cluster by focusing on a specific sequence of episodes in which stakeholders interact to resolve different of interest and conflicts.

\section{METHODOLOGY}

The research was conducted in Gemah Ripah 2 farmer group, Japara village, Japara subdistrict, Kuningan District trough qualitative descriptive survey. About 20 respondents was interviewed to grasp a deep understanding regarding the development of sustainable agricultural system in Gemah Ripah 2 farmer group, which has been collaboration with Universitas Padjadjaran, and local government. Key informant was interviewed to validate the data. The case was chosen due to the development of sustainable agribusiness process that is impacted several dilemmas between Gemah Ripah 2 farmer group, university, and local government. The data was analyzed and modeled by using confrontation Manager with drama theory approach. 
Drama theory is an analysis about the importance of irrationality, preference change, emotion, and political aspects of choice in interdependent decision making situations. Drama theory uses dilemmas to analyze, predict, and understand the pressure on characters to change their positions, preferences, and common reference frame. Drama theory is a method to deal with paradoxes of rationality or dilemmas of interaction decision making include metagame and hypergame analysis (Bennett et al., 2001; Howard, 1971). Drama theory is used to analyze how a framework could be changed to the other framework in a series of episodes (Howard et al., 1992). Framework changing takes place due to the presence of dilemmas. Dilemmas happened if there are hampering to achieve an objective. The objective is reflected in the form of position (open future scenario) that tries to convenience other stakeholders to accept the position, with promise or threat if necessary.

\section{RESULT AND DISSCUSION}

\subsection{Sustainable Agribusiness Cluster in Kuningan District}

Sustainable agribusiness cluster in Kuningan District-West Java has been developed since 2015. The development of the cluster is the result of collaboration between Gemah Ripah 2 farmer group and Universitas Padjadjaran supported by Bank Indonesia Cirebon region, local government of Kuningan district, and Universitas Kuningan. The main actors of this collaboration are Universitas Padjadjaran as academicians and researcher, Gemah Ripah 2 farmer group as an implementation object, and local government (including Bank Indonesia region Cirebon and local government (Pemda) in Kuningan District). Collaboration of sustainable agribusiness cluster implemented the integration farming system of agriculture (rice), fisheries (tilapia and nilem fish), and livestock (cattle and padjadjaran sheep).

The collaboration is aimed to increase competitive advantage and value added, hereinafter, decreasing poverty and increasing welfare is a goal of this collaboration. The concept of this sustainable agribusiness cluster is to serve high quality products for consumers so that farmers and market can get highest profit. On the other hand, the development of collaboration was set to achieve sustainability between multi-stakeholders and multi-commodities. The actors are collaborating by sharing the roles and resources to support the enterprise developed. Each actor has a support action such as field assistance, demonstrating plots, and visit study to improve the farming capacity of the farmer's community.

\subsection{Dilemma Analysis}

The concept is developing multi-commodities which performed several benefits, i.e., improving social benefit for farmers, improving economic and environmental advantages, improving knowledge both for farmers, university and local government in the implementation of sustainable agribusiness. Meanwhile, implementation of sustainable agribusiness cluster is inflicting positive and negative impact for stakeholders. The collaboration of sustainable agribusiness cluster faced several dilemmas for all stakeholders.

Every party in sustainable agribusiness cluster tends to achieve their own objectives. Farmers refused to implement sustainable agribusiness and prefer to implement traditional farming that did not give more benefits. Meanwhile, Universitas Padjadjaran as an academician needs support from several stakeholders in the implementation of sustainable agribusiness cluster. Universitas Padjadjaran should develop sustainable agribusiness cluster based on research and combined with environmental and social condition. Local government needs to ensure that this program is eligible with government program. 


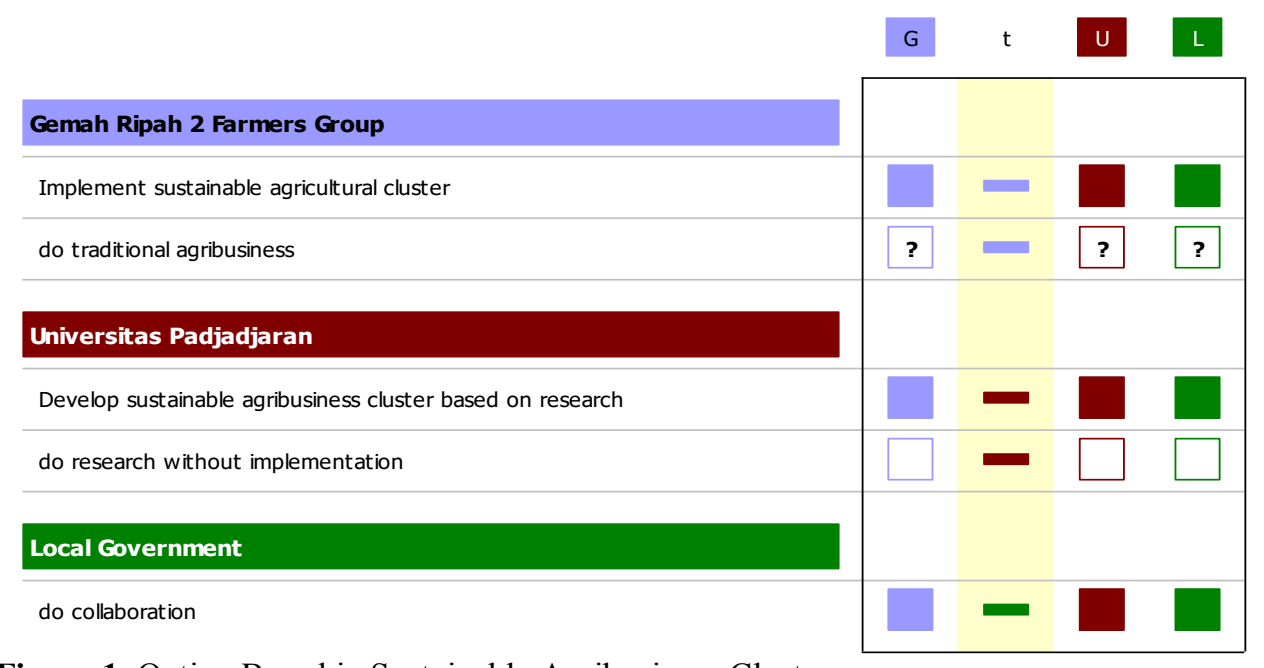

Figure 1. Option Board in Sustainable Agribusiness Cluster

\author{
Additional Information; \\ G - Gemah Ripah 2 Farmer Group $\quad$ U - Universitas Padjadjaran $\quad$ L - Local Government \\ : Adopted $\square$ : Left open $\mathbf{t}$-Threatened Future $\square$ : Rejected ?: Doubted
}

In regard to the collaboration, each party tries to issues their threatened future; Gemah Ripah 2 farmer group may or may not implement sustainable agribusiness cluster, because Gemah Ripah 2 farmer group doubted to Universitas Padjajdaran and local government. Universitas Padjadjaran will increase agribusiness system based on research and in the practice of sustainable agribusiness; Universitas Padjadjaran does assistance and facilitate to help farmers in the implementation of sustainable agribusiness. Furthermore, Local Government might do collaboration, it is because local government doubted to Universitas Padjadjaran in the implementation of sustainable agribusiness cluster continuously.

\title{
3.2.1 Gemah Ripah 2 Farmer Group
}

Gemah Ripah 2 farmer group faced cooperation dilemmas with respect to Universitas Padjadjaran and local government. Gemah Ripah 2 farmer group doubted that Universitas Padjadjaran and local government would assist and support farmers in the practice of sustainable agribusiness. Gemah Ripah 2 farmer group must gain trust from Universitas and local government that Gemah Ripah 2 farmer group is capable to implement sustainable agribusiness. Project course of action for Gemah Ripah 2 farmer group are all stakeholders should agree to Gemah Ripah 2 farmer group position, this group would incur in carrying out these commitments and inevitably carry them out. Gemah Ripah 2 farmer group should apply positive emotion towards Universitas Padjadjaran and local government. By convincing Universitas Padjadjaran and local government that Gemah Ripah 2 farmer group position is better for Universitas Padjadjaran that might not only do research without implementation but also collaboration with farmer group. Gemah Ripah 2 farmer group might show the advantages to Universitas Padjadjaran of sticking to Gemah Ripah 2 farmer group position is greater or more credible than universitas padjadjaran and local government supposes, to make it serious, Gemah Ripah 2 farmer group should apply positive emotion toward Universitas Padjadjaran and local government. 


\subsubsection{Universitas Padjadjaran}

Universitas Padjadjaran has a dilemma in the implementation of sustainable agribusiness cluster in Kuningan District. Universitas Padjadjaran has trust dilemma with respect to Gemah Ripah 2 farmer group. Universitas Padjadjaran doubts Gemah Ripah 2 farmer's group would actually implement its proposals. Universitas Padjadjaran must make Gemah Ripah 2 farmer group trustworthy. Universitas Padjadjaran analyzes Gemah Ripah 2 farmer group concerns to see why, after agreeing to Universitas Padjadjaran position, Gemah Ripah 2 farmer group might do traditional agribusiness again and left sustainable agribusiness concept. Universitas Padjadjaran should show that Universitas Padjadjaran position is greater or more incredible that Gemah Ripah 2 farmer group supposes. Universitas Padjadjaran also needs to show the advantage to Gemah Ripah 2 farmer group of sticking to Universitas Padjadjaran's position are great or more credible, than Gemah Ripah 2 farmer group supposes. Project emotion of Universitas Padjadjaran should show mistrustful or neutral toward Gemah Ripah 2 farmer group.

\subsubsection{Local Government}

Local government has a dilemma towards Gemah Ripah 2 farmer group in the implementation of sustainable agribusiness. Local government has trust dilemma with respect to Gemah Ripah 2 farmer group. Local government doubted that Gemah Ripah 2 farmer group would actually implement its proposal. Local government must make Gemah Ripah 2 farmer group trustworthy. Local government analyzes Gemah Ripah 2 farmer group concerns to see why, after agreeing to local government position that Gemah Ripah 2 farmer group might do traditional agribusiness and refuse to implement sustainable agribusiness. Local government should show greater position or more credible than Gemah Ripah 2 farmer group supposes. Local government also needs to show the advantages to gemah Ripah 2 farmer group of sticking to local government's position are greater than Gemah Ripah 2 farmer group supposes. Local government should show mistrustful or neutral emotion toward Gemah Ripah 2 farmer group. This emotion is to ensure that Gemah Ripah 2 farmer group and local government will be capable to develop sustainable agribusiness by doing collaboration with Universitas Padjadjaran.

\section{CONCLUSION}

This paper describes about sustainable agribusiness cluster, and this collaboration between Gemah Ripah 2 farmer group, Universitas Padjadjaran, and local government. In regard to this paper, each party has dilemmas about implementation of sustainable agribusiness; the dilemmas are about trustworthy and cooperation dilemmas in the implementation of sustainable agribusiness. The multi-stakeholders who were involved in the collaboration of sustainable agribusiness cluster should develop better relationship, maintain communication between each actor, and the actors realize that this collaboration has long term relationship to gain more profit through collaboration in the development of sustainable agribusiness cluster. However, some parties are still doubt and lack of trust to the other party to implement the collaboration and show the position that might interfere the collaboration.

\section{SUGGESTION}

Development of sustainable agribusiness by involving multi-stakeholders should develop several strategies, i.e., development intensive communication between Gemah Ripah 2 
farmer group, Universitas Padjadjaran, and local government. According to Duncan et al. (1998), communication in the development of collaboration is the foundation and critical element in the collaboration. Intensive communication should develop better relationship and improve trustworthy among parties. Discussion about the process of development should reduce the problem and build trustworthy. According to Handayani et al. (2015), develop supply chain relationship among actors is one of the important part to improve food supply and gain value co-creation.

Warm thanks to Ministry of Research, Technology, and Higher Education of the Republic Indonesia and Universitas Padjadjaran which founded the research through Iptek Bagi Wilayah (IbW) Perguruan Tinggi (PT) Local government-CSR with the tittle IbW "Development of agribusiness cluster with integration between vegetables and sheep padjadjaran" and Central bank of Indonesia Cirebon region, local government Kuningan district, and Universitas Kuningan as partner in the implementation of the IbW research in Kuningan District from 2016-2018.

\section{REFERENCES}

[1] Pasandaran E, Djajanegara A, Kariyasa K, and Kasryno F. Integrasi Tanaman Ternak di Indonesia, Badan penelitian dan Pengembangan Pertanian. Jakarta. (2006)

[2] De Bon, H., Parrot, L. and Moustier, P. Sustainable urban agriculture in developing countries. A review. Agronomy for sustainable development, 30 (1), pp.21-32. (2010)

[3] Porter, M. E. Location, competition, and economic development: Local clusters in a global economy. Economic development quarterly, 14 (1), 15-34. (2000).

[4] Toma E. Agribusiness Cluster - Between Theory and Practices, Scientific Papers Management, Economic Engineering in Agriculture and Rural Development. Vol 9 No 3. 58. (2009).

[5] Geldes, C., Felzensztein, C., Turkina, E. and Durand, A. How does proximity affect interfirm marketing cooperation? A study of an agribusiness cluster. Journal of Business Research, 68 (2), pp.263-272. (2015)

[6] Matopoulos, A., Vlachopoulou, M., Manthou, V. and Manos, B. A conceptual framework for supply chain collaboration: empirical evidence from the agri-food industry. Supply Chain Management: an international journal, 12 (3), pp.177186.(2007)

[7] Van't Hooft, K. Livestock, the World, and the Dutch-Part II. Institute for Agricultural Market Studies (IKAR) Russia Dairy Industry Profile http://www. ikar. ru/eng (retrieved). (2013)

[8] Howard, N. Confrontation Analysis: How to Win Operations rather than War.CCRP, Department of defense, Washington, DC. (1999).

[9] O'Malley, P. Value Creation and Business Success. The Systems Thinker, 9 (2). (1998).

[10] Bennet, P.G. Bryant, J. and Howard, N. 'Drama theory and confrontation analysis', in Rosenhead, J.V. and Mingers, J. (Eds.): Rational Analysis for a Problematic World Revisited, pp.225-248, Wiley, New York. (2001)

[11] Howard, N. Paradoxes of Rationality: Games, Metagames, and Political Behavior, MIT Press, Cambridge, MA. (1971)

[12] Howard, N., Bennett, P.G., Bryant, J.W., and Bradley, M. Manifesto for a theory of drama and irrational choice.Journal of Operational Research Society, 44, 99103.(1992).

[13] Duncan, Tom, and Sandra E. Moriarty. "A communication-based marketing model for managing relationships." The Journal of marketing : 1-13. (1998)

[14] Handayati, Yuanita, Togar M. Simatupang, and Tomy Perdana. "Value Co-creation in Agri-chains Network: An Agent-Based Simulation." Procedia Manufacturing 4: 419428. (2015) 